\title{
Zinc oxide nanoparticles induce photocatalytic cell death in human head and neck squamous cell carcinoma cell lines in vitro
}

\author{
STEPHAN HACKENBERG, AGMAL SCHERZED, MICHAEL KESSLER, KATRIN FROELICH, \\ CHRISTIAN GINZKEY, CHRISTIAN KOEHLER, MARC BURGHARTZ, \\ RUDOLF HAGEN and NORBERT KLEINSASSER
} Department of Otorhinolaryngology, Plastic, Aesthetic and Reconstructive Head and Neck Surgery,
University of Wuerzburg, Josef-Schneider-Strasse 11,97080 Wuerzburg, Germany

Received June 16, 2010; Accepted August 12, 2010

DOI: 10.3892/ijo_00000812

\begin{abstract}
The aim of this study was to determine the photocatalytic effects of zinc oxide $(\mathrm{ZnO}) \mathrm{NPs}$ in combination with UVA-1 in human head and neck squamous cell carcinoma (HNSCC) cell lines in vitro. NP characteristics and intracellular distribution were described by transmission electron microscopy (TEM). After pre-incubation with ZnO NPs in concentrations of $0.002-20 \mu \mathrm{g} / \mathrm{ml}$, the HNSCC cell lines HLaC 78 and UD-SCC 7A as well as primary oral mucosa cells (pOMCs) were treated with UVA-1. Cell survival and vitality was observed by 3-(4,5-dimethylthiazol-2-yl)-2,5diphenyl-tetrazoliumbromide-(MTT)-assay and fluorescein diacetate test. Apoptosis was assessed by annexin-V propidium iodide flow cytometry. Intranuclear distribution of the rod-shaped particles was observed in $3.5 \%$ of HNSCC and in $0.5 \%$ of pOMCs. UVA-1 irradiation of $15 \mathrm{~min}$ in combination with 0.2 and $2 \mu \mathrm{g} / \mathrm{ml}$ of $\mathrm{ZnO} \mathrm{NP}$ dispersion was shown to reduce the vitality of cancer cell lines significantly in comparison to cells without NP exposure or UVA-1 treatment only. For HLaC 78, a significant reduction in viable cells was already seen at $10 \mathrm{~min}$ of UVA-1 treatment and a $\mathrm{ZnO} \mathrm{NP}$ concentration of $2 \mu \mathrm{g} / \mathrm{ml}$. Flow cytometry indicated that cell death occurred primarily through necrosis. In pOMCs, vitality was not influenced either by UVA-1 treatment or $\mathrm{ZnO}$ NP exposure up to $2 \mu \mathrm{g} / \mathrm{ml}$ or a combination of both. $\mathrm{ZnO}$ NPs showed cytotoxicity at $20 \mu \mathrm{g} / \mathrm{ml}$ without UVA-1. Due to their photocatalytic properties, ZnO NPs may induce cell death in human HNSCC cell lines in vitro. Further studies will evaluate a possible benefit in adjuvant cancer therapy.
\end{abstract}

Correspondence to: Dr Norbert Kleinsasser, Department of Otorhinolaryngology, Plastic, Aesthetic and Reconstructive Head and Neck Surgery, University of Wuerzburg, Josef-Schneider-Str. 11, D-97080 Wuerzburg, Germany

E-mail: kleinsasser_n@klinik.uni-wuerzburg.de

Key words: nanoparticles, zinc oxide, UV irradiation, cancer treatment, photocatalytic effect, head and neck squamous cell carcinoma

\section{Introduction}

In 2009, 48,000 new cases of carcinomas of the oral cavity, the pharynx and the larynx were estimated, representing 3\% of all new malignant diseases in the USA (1). In 2002, there were $\sim 350,000$ deaths from head and neck cancer, accounting for $5.2 \%$ of all cancer deaths worldwide according to the GLOBOCAN database. Approximately $90 \%$ of the head and neck cancer cases are squamous cell carcinomas (HNSCC) (2). HNSCC is associated with excessive consumption of alcohol and smoking tobacco (3). Patients with early stage disease may be treated by surgery, sometimes in combination with radiotherapy. Nearly $80 \%$ of these patients can be cured, depending on the extent of the disease (4). For advanced HNSCC, combined therapy regimes are required (5). In addition to surgical measures, radiation and chemotherapy represent main treatment pathways. Cisplatin or carboplatin are the most commonly applied chemotherapeutic agents and a combination with 5-fluorouracil or taxanes may be used. The duration and intensity of chemotherapy is limited due to the toxicity of the components (6). Despite significant advances in therapy procedures including surgery, radiation and chemotherapy, little improvement in the prognosis of HNSCC has been achieved over the last three decades (7). Thus, novel therapy strategies need to be evaluated and assessed to ameliorate current treatment regimes.

Nanoparticles (NPs) are defined as materials on the nanometer scale which are $<100 \mathrm{~nm}$ in diameter. These particles exhibit specific physicochemical properties and functions (8-10). Due to their dimensions, nanoparticles show a different relationship between mass and surface compared to their bulk substance $(11,12)$. Nano-sized particles of many different metal and ceramic oxides are currently manufactured commercially for applications including high-performance composite materials, photochemically active or wavelength selective surface coatings, cosmetics and process catalysts (13).

Nano-sized zinc oxide $(\mathrm{ZnO})$ is used in industrial products including cosmetics, paints and medical materials. As a wellknown photocatalyst, $\mathrm{ZnO}$ has received much attention in the degradation and complete mineralization of environmental pollutants (14), comparable to titanium dioxide $\left(\mathrm{TiO}_{2}\right)$ NPs 
(15). Regarding $\mathrm{TiO}_{2}$ NPs, tumour cell elimination induced by photocatalytic mechanisms was described for a human colon carcinoma cell line (Ls-174-t) and a human melanoma cell line (A-375) $(16,17)$. Since $\mathrm{ZnO}$ has almost the same band gap energy $(3.2 \mathrm{eV})$ as $\mathrm{TiO}_{2}$, its photocatalytic capacity is anticipated to be similar to that of $\mathrm{TiO}_{2}$ (18). The aim of the present study was to investigate possible photocatalytic effects of ZnO NPs on human HNSCC cell lines and nonmalignant cells in vitro and to evaluate the impact of this novel adjuvant treatment pathway.

\section{Materials and methods}

Reagent preparation. $\mathrm{ZnO}-\mathrm{NPs}(<100 \mathrm{~nm}$, surface area $15-$ $25 \mathrm{~m}^{2} / \mathrm{g}$ ) were obtained as a powder from Sigma-Aldrich (Steinheim, Germany). Before inoculation into the in vitro system, the particles were suspended in sterilised distilled water. The stock suspension of $50 \mu \mathrm{g} / \mathrm{ml}$ was then sonicated (Bandelin, Sonopuls HD 60, Berlin, Germany) for $60 \mathrm{sec}$ at a high energy level of $4.2 \times 10^{5} \mathrm{~kJ} / \mathrm{m}^{3}$ using a continuous mode to create a high grade of dispersion. Bovine serum albumin (BSA) was added at an end concentration of $1.5 \mathrm{mg} / \mathrm{ml}$ to stabilise the suspension. Finally, $10 \mathrm{X}$ concentrated phosphatebuffered saline (PBS) was added to achieve a physiological salt concentration and $\mathrm{pH} 7.4$ (19). This stock suspension was subsequently diluted with PBS.

Characterisation of nanoparticles. The morphology, size and size distribution of nanoparticles in the stock dispersion was determined by transmission electron microscopy (TEM). After sonication and stabilisation, the TEM samples were prepared by drop coating of the stock suspension onto carboncoated copper grids. The film on the grids was dried using a tissue paper prior to measurement. The particle characterisation included shape, size and tendency of aggregation. The evaluation was performed on a Zeiss transmission electron microscope EM 900 (Carl Zeiss, Oberkochen, Germany) at the Division of Electronmicroscopy at the University of Wuerzburg Biocenter. Photographic negatives were digitalised and then nanoparticle size was evaluated. Two hundred particles were measured for each sample.

Cell lines and cell cultures. Two tumour cell lines and primary human oral mucosal cells were investigated: First, the human head and neck squamous carcinoma cell line HLaC 78 was used. It was established from the lymph node metastasis of a laryngeal squamous cell carcinoma (20). Further, UD-SCC 7A was investigated as the second human HNSCC cell line (21). Tumour cells were cultured in RPMI-1640 medium (Biochrom AG, Berlin, Germany) supplemented with $10 \%$ fetal calf serum (FCS), $100 \mathrm{U} / \mathrm{ml}$ penicillin, $100 \mu \mathrm{g} / \mathrm{ml}$ streptomycin, $1 \% 100 \mathrm{mM}$ sodium pyruvate (Biochrom AG) and $1 \%$ of a 100 -fold concentration of non-essential amino acids (Biochrom AG). The cells were incubated at $37^{\circ} \mathrm{C} / 5 \%$ $\mathrm{CO}_{2}$ in 75 or $150 \mathrm{~cm}^{2}$ flasks, replacing the media every second day and passaging before reaching $80 \%$ of cell confluence by trypsinization (0.25\% trypsin; Gibco, Eggenstein, Germany), washing and seeding in new flasks or treatment wells.

Specimens from human mucosa of the anterior or posterior palatal arch of three male patients (median age 25) were obtained during uvulopalatopharyngoplasty. Since only mucosa resected for surgical reasons was investigated, there was no additional risk for the patients. The patients had signed an informed consent statement, and the study was approved by the Ethics Board of the Medical Department of the JuliusMaximilian-University of Wuerzburg. In order to prepare primary oral mucosa cells (pOMC) from the palatinal mucosa, tissue samples were incubated in dispase for $12 \mathrm{~h}(25 \mathrm{U} / \mathrm{ml}$, Boehringer-Mannheim, Germany). Subsequently, epithelial sheets were dissected manually and dissociated with trypsin (Gibco). Dissociation was stopped with soybean trypsin inhibitor $(10 \mathrm{mg} / \mathrm{ml}$, Gibco) and cells were cultivated in keratinocyte-SFM (serum-free medium for keratinocytes, Gibco) at $37^{\circ} \mathrm{C}$ and $5 \% \mathrm{CO}_{2}$ and passaged twice before use (22). Experiments were performed using cells in the exponential growth phase. Before exposure to the particles, cells were counted by an electronic cell counter (Casy ${ }^{\circledR}$ Technology, Innovatis AG, Reutlingen, Germany) and seeded in a $24-w e l l$ round bottom plate $\left(1 \times 10^{5}\right.$ cells per well $)$, allowing a recovery period of $24 \mathrm{~h}$ to provide attachment and further proliferation.

Cell proliferation analysis. HLaC 78 cells $\left(1 \times 10^{4}\right)$, UD-SCC 7A cells or pOMCs were seeded in a 12-well round bottom plate and incubated for up to 5 consecutive days with RPMI medium for tumour cells and keratinocyte-SFM for pOMCs at $37^{\circ} \mathrm{C}$ and $5 \% \mathrm{CO}_{2}$. The proliferation was analysed on days $2-5$ by counting the cells in a Neubauer chamber after trypinisation. For the calculation of cell number duplication time, the following formula was used: Duplication time $=\log$ $2 \mathrm{x}$ duration of cultivation $[\mathrm{h}] / \log (\mathrm{N})-\log (\mathrm{N} 0)$. N, number of cells after cultivation; NO, number of cells at the beginning.

Cell treatment and UV irradiation. Nanoparticle suspension $(10 \mu \mathrm{l})$ was added to the 24-well round bottom plates $24 \mathrm{~h}$ after cell seeding in order to achieve final NP concentrations of $0.002,0.02,0.2,2$ and $20 \mu \mathrm{g} / \mathrm{ml}$. After another $24 \mathrm{~h}$ of incubation at $37^{\circ} \mathrm{C} / 5 \%, \mathrm{CO}_{2}$ plates were irradiated with a 4-kW UV lamp (Sellamed 4000, Gevelsberg, Germany) in the Department of Dermatology phototherapy unit at the University Clinics of Wuerzburg. A UV pass filter was used to obtain a light wavelength between 340 and $440 \mathrm{~nm}$. The light intensity at the liquid surface was measured using a Variocontrol UV meter (Waldmann, Villingen-Schwenningen, Germany). The incident light intensity of the UVA-1 irradiation $(365 \mathrm{~nm})$ was $20 \mathrm{mWcm}^{-2}$. Exposure durations were set at 5,10 and $15 \mathrm{~min}$. Three groups of experimental settings were provided. The first group was treated with different concentrations of nanoparticles in the absence of UVA-1. The second group was treated with nanoparticles combined with irradiation by UVA-1. The third group was irradiated in the absence of nanoparticles. Following photo treatment and prior to further investigation, cells were again incubated at $37^{\circ} \mathrm{C} / 5 \% \mathrm{CO}_{2}$ for $24 \mathrm{~h}$. For the evaluation of morphological changes, cells were collected by centrifugation after postinterventional incubation and resuspended in medium. Further analysis was performed with the aid of an inverted phasecontrast microscope (Leica DMIL, Wetzlar, Germany). All experiments were performed in triplicate. 
A

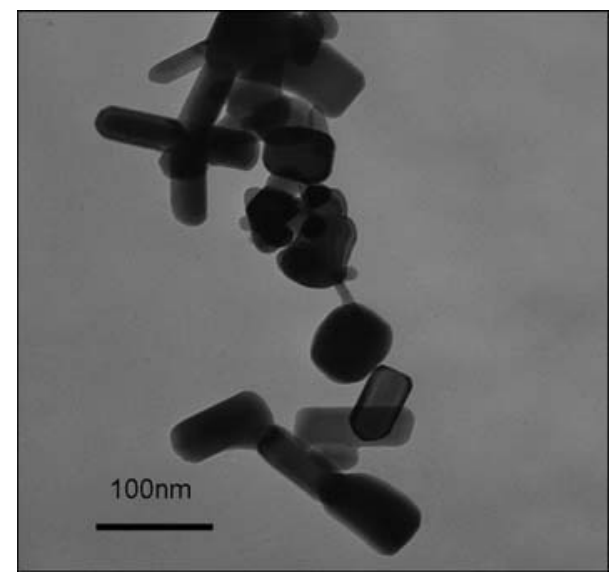

B

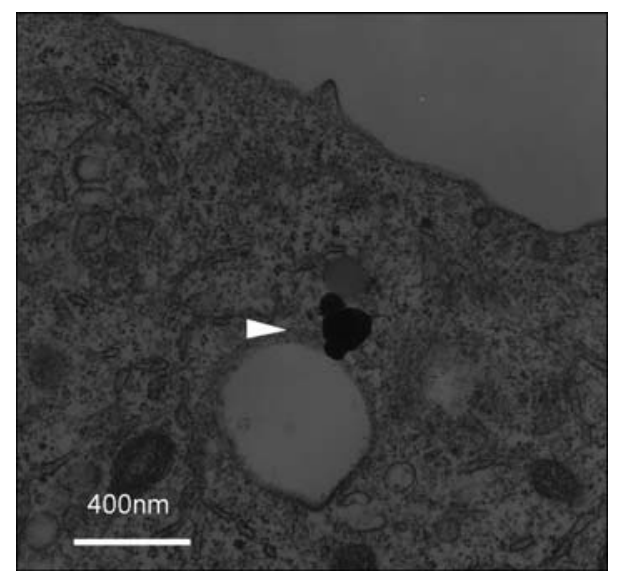

C

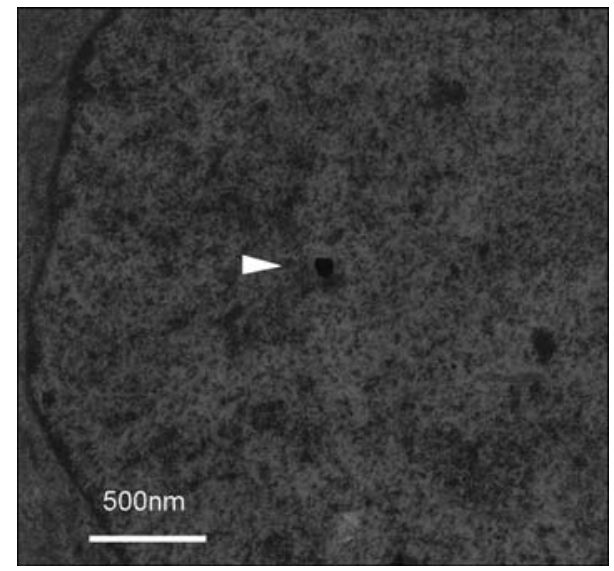

Figure 1. (A) Characterisation of nanoparticles: TEM photograph shows rod-shaped ZnO NPs in aggregation. Primary particles are $30-135 \mathrm{~nm}$ in size (scale bar represents $100 \mathrm{~nm}$, image was taken at x80,000 magnification). (B) Ultrastructural study of cell invasion: TEM photograph shows an intracytoplasmatic particle aggregate (indicated by the white arrow) next to a vesicula (scale bar represents $400 \mathrm{~nm}$, image was taken at x 20,000 magnification). (C) TEM photograph shows a ZnO NP (indicated by the white arrow) in the cell nucleus. Intranuclear particle distribution could be observed in $3.5 \%$ of HLaC 78 and in $3.5 \%$ of UD-SCC 7A cells (images were taken at $\mathrm{x} 15,000$ magnification).

Cell preparation for TEM. For the ultrastructural study of the intracellular distribution of nanoparticles, cell pellets were obtained after $24 \mathrm{~h}$ of exposure. They were fixed in a fresh solution of $0.1 \mathrm{M}$ sodium cacodylate containing $2.5 \%$ glutaraldehyde and $2 \%$ formaldehyde followed by a 2 -h fixation at $4^{\circ} \mathrm{C}$ with $2 \%$ osmium tetroxide in $50 \mathrm{mM}$ sodium cacodylate ( $\mathrm{pH} 7.2)$. Staining was performed overnight with $0.5 \%$ aqueous uranyl acetate. Specimens were dehydrated, embedded in Epon 812 and ultrathin sections were prepared. The sections were examined with an EM900 electron microscope (Carl Zeiss) and photographic negatives were digitalised by scanning and processed using Adobe Photoshop.

MTT cytotoxicity assay. After exposure and consecutive incubation for $24 \mathrm{~h}$, the viability of cells was studied using the MTT [3-(4,5-dimethylthiazol-2-yl)-2,5-diphenyl tetrazolium bromide] colorimetric staining method (23). All plates were incubated with medium containing $1 \mathrm{mg} / \mathrm{ml}$ of MTT (SigmaAldrich). The medium from each well was replaced by isopropanol after $4 \mathrm{~h}$ of inoculation at $37^{\circ} \mathrm{C}$ with $5 \% \mathrm{CO}_{2}$. Isopropanol was allowed to solubilise the resulting formazan crystals overnight at $37^{\circ} \mathrm{C}$ with $5 \% \mathrm{CO}_{2}$. The colour conversion of the blue formazan dye was measured by an ELISA (enzyme linked immunosorbent assay) reader at a wavelength of $570 \mathrm{~nm}$.

Fluorescein diacetate test. Additionally, cells were stained with a 1:1 solution of fluorescein diacetate (FDA, $80 \mu \mathrm{g} / \mathrm{ml}$ ) and ethidium bromide $(50 \mu \mathrm{g} / \mathrm{ml})$. The samples were observed using a DMLB fluorescence microscope (Leica Microsystems, Wetzlar, Germany) with an excitation filter of $488 \mathrm{~nm}$ (blue light). Living cells were stained green while dead cells exhibited their nucleus stained with orange. The survival percentage was obtained by dividing the number of living cells by the total number of cells.

Annexin V-propidium iodide staining apoptosis test. Apoptosis and necrosis were measured by flow cytometry using an Annexin V-propidium iodide kit (Becton-Dickinson Biosience, Heidelberg, Germany) according to the manufacturer's protocol. Twenty-four hours after the UVA irradiation, the medium was transferred to a 5-ml culture tube. Adherent cells were harvested by trypsinisation and added to the preserved medium. Following two washing steps with PBS, the cell pellet was resuspended with ice cold binding buffer $(0.1 \mathrm{M}$ HEPES, pH 7.4, 1.4 M NaCl, $25 \mathrm{mM} \mathrm{CaCl}_{2}$ ). Annexin $\mathrm{V}$ and propidium iodide staining was carried out by addition of $5 \mu \mathrm{l}$ Annexin V-APC and $5 \mu 1$ propidium iodide (PI) to each sample and incubation for $15 \mathrm{~min}$ in the dark at room temperature. Fluorescence was measured using flow cytometry (FACScanto, Becton-Dickinson). PI staining is able to detect cells with permeable membranes, as observed during necrosis or late apoptotic events (24).

Statistical analysis. For statistical analysis, Student's t-test for paired data was applied to evaluate significant differences between samples. Differences were considered statistically significant at $\mathrm{P}<0.05$.

\section{Results}

Ultrastructural studies. Transmission electron microscopy (TEM) was used to obtain information about diameter, size distribution, morphology, aggregation and cellular invasion of $\mathrm{ZnO}-\mathrm{NPs}$. Particles were rod-shaped with a longitudinal diameter of $79 \pm 32 \mathrm{~nm}$ (mean $\pm \mathrm{SE}$ ) and a lateral diameter of $46 \pm 17 \mathrm{~nm}$ (mean $\pm \mathrm{SE}$ ). These findings agree with the manufacturer's specific size information. Commonly, NPs were 


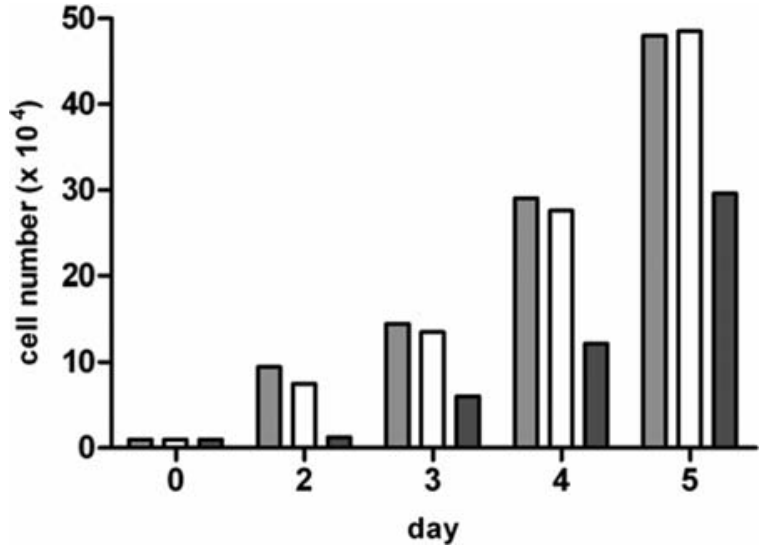

Figure 2. Evaluation of cell proliferation of HNSCC cell lines (HLaC 78: light gray columns; UD-SCC 7A: white columns) and oral mucosa cells (pOMC: dark gray columns) on days 2-5 after seeding.

united to aggregates with a volume of up to 200 single NPs. Isolated particles were only seen sporadically (Fig. 1A). For the evaluation of intracellular particle distribution, 200 cells of each sample were observed by TEM. The rate of cells with intracytoplasmatic ZnO NPs was $11.5 \%$ for HLaC 78, $8.0 \%$ for UD-SCC 7A (Fig. 1B) and 9.0\% for pOMCs. Particle invasion into the cell nucleus could be observed in $3.5 \%$ of HLaC 78 (Fig. 1C), in $3.5 \%$ of UD-SCC 7A and in $0.5 \%$ of pOMCs.

Cell proliferation. Cell proliferation was documented for HLaC 78, UD-SCC 7A and pOMCs cultivated in cell growth medium without NPs. Results are shown in Fig. 2, showing a higher proliferation rate for tumour cells compared to pOMCs. Cell number duplication time was $14.8 \mathrm{~h}$ for HLaC 78, $18.5 \mathrm{~h}$ for UD-SCC 7A and $76.7 \mathrm{~h}$ for pOMCs.

Cytotoxicity. The cell viability was observed by MTT assay $24 \mathrm{~h}$ after exposure to UVA-1. Both tumour cell lines and pOMCs showed no reduction in cell viability following $\mathrm{ZnO}$ NP exposure without UVA-1 irradiation for particle concentrations in the growth medium up to $2 \mu \mathrm{g} / \mathrm{ml}$ (Fig. 3A). In contrast, the highest NP concentration of $20 \mu \mathrm{g} / \mathrm{ml}$ caused a significant reduction in viable cells for HNSCC cell lines and pOMC in all settings, even without UVA-1 treatment. After
$\mathbf{A}$

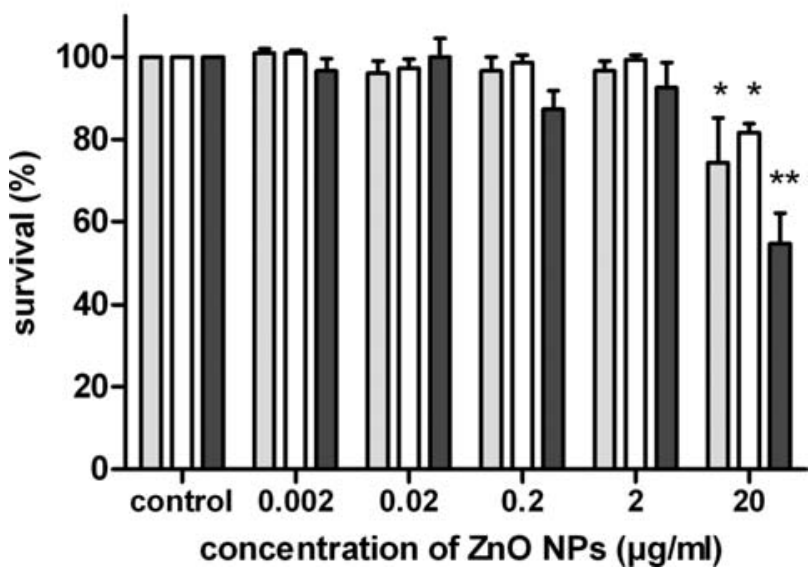

C

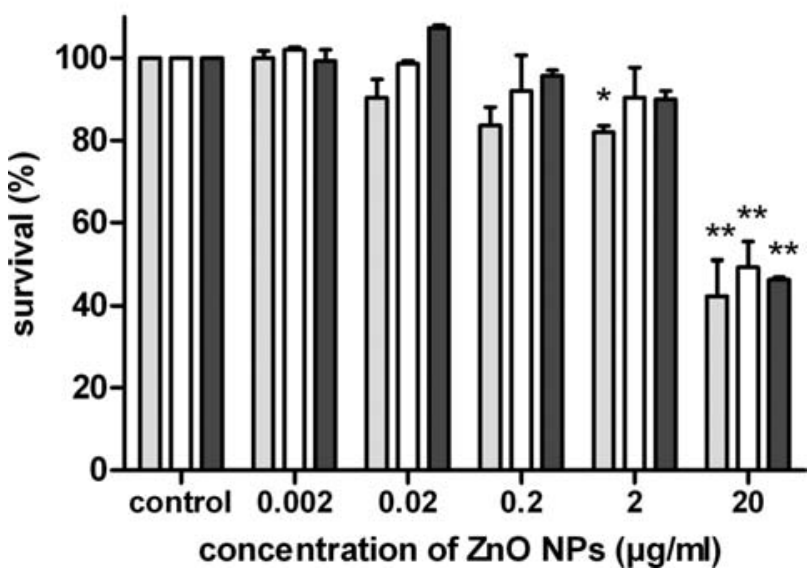

B 5 minutes UVA

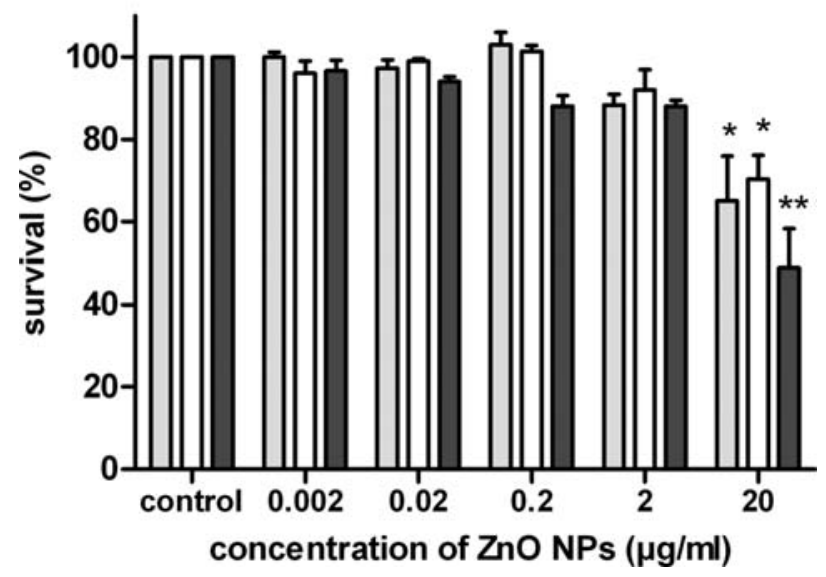

15 minutes UVA

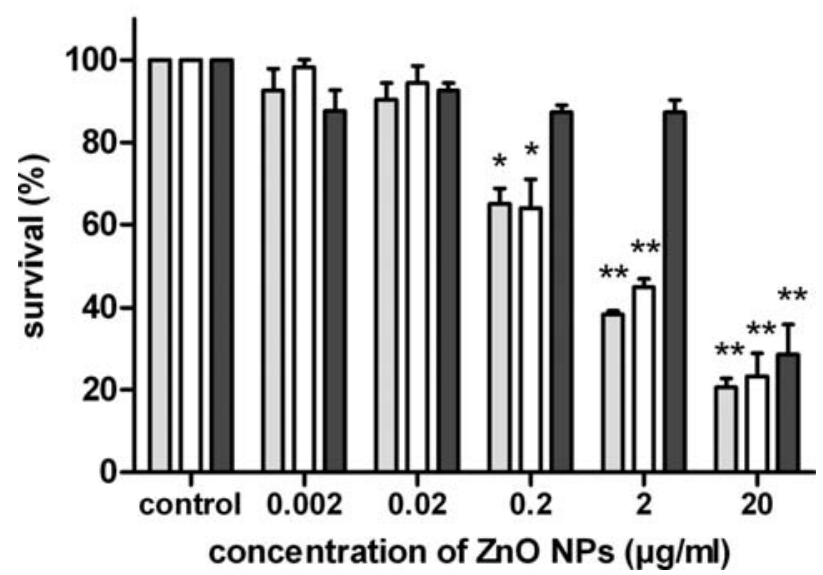

Figure 3. Survival of HLaC 78 (light gray columns), UD-SCC 7A (white columns) and pOMC (dark gray columns) as function of ZnO NP concentration. Columns show the mean values and the standard deviation. Significance compared to the control with a $\mathrm{P}$-value $<0.05 /<0.005$ is indicated by asterisks ${ }^{* * *}$. (A) Cell survival following exposure to $\mathrm{ZnO}$ NP without UVA-1 treatment. (B) Cell survival after exposure to ZnO NP and 5 min of UVA-1 irradiation. (C) Cell survival following exposure to ZnO NP and UVA-1 treatment of $10 \mathrm{~min}$. (D) Cell survival after ZnO NP exposure and 15 min of UVA-1 therapy. 
A

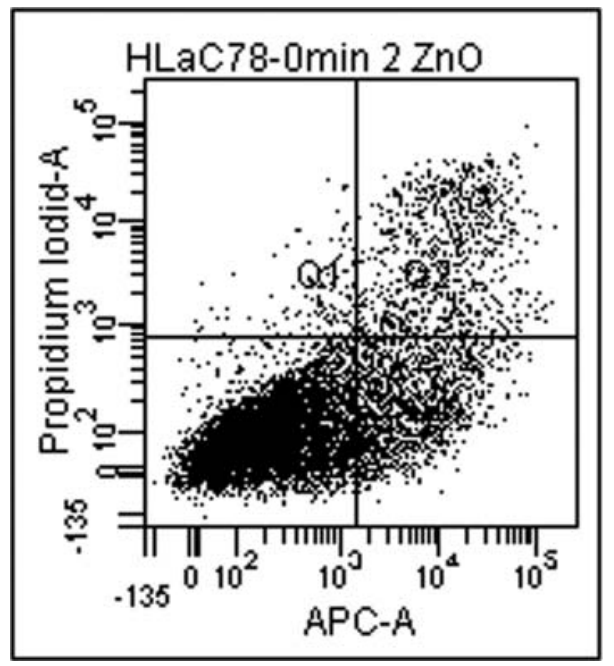

C

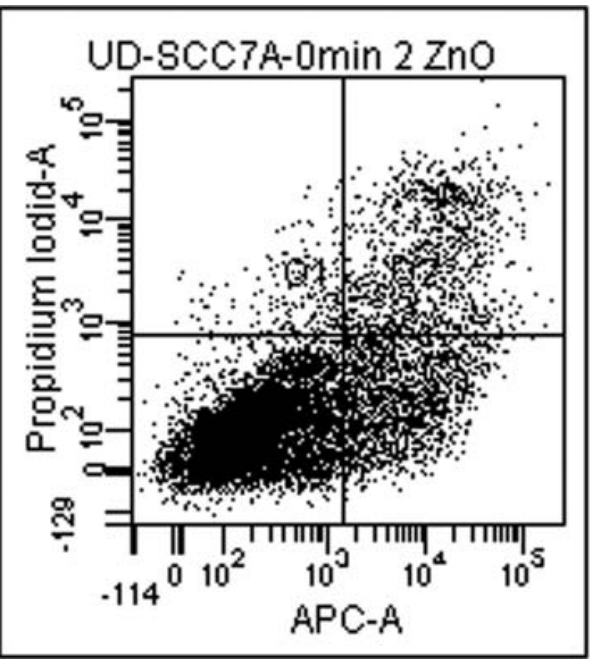

E

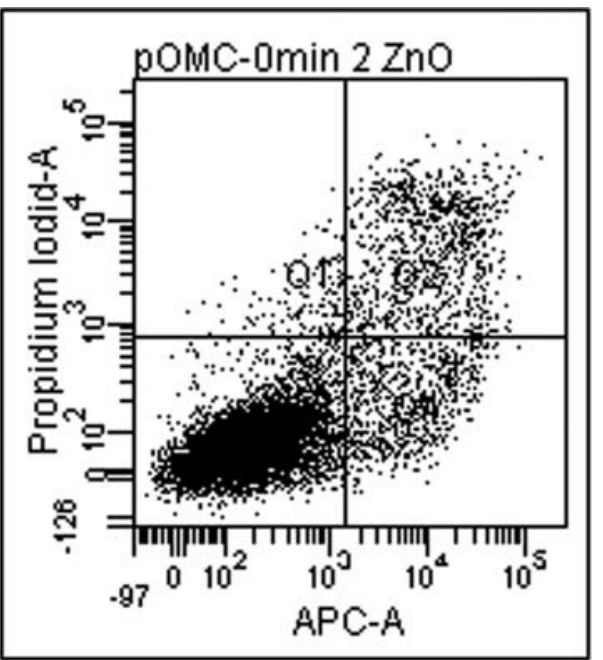

B

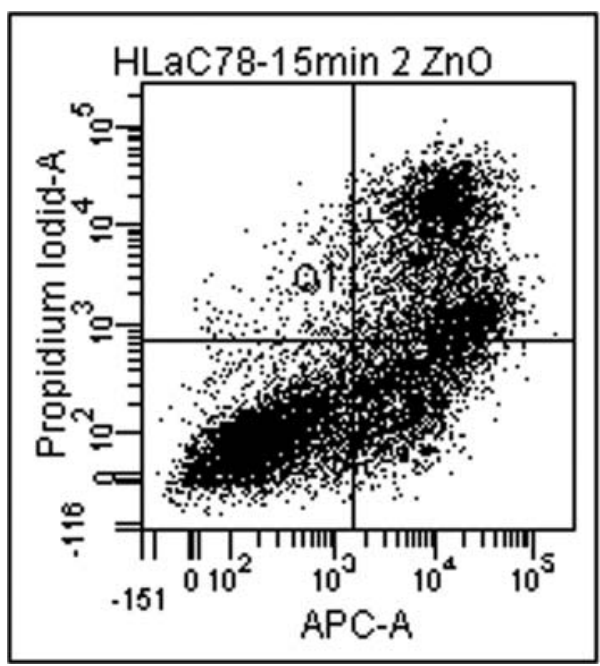

D

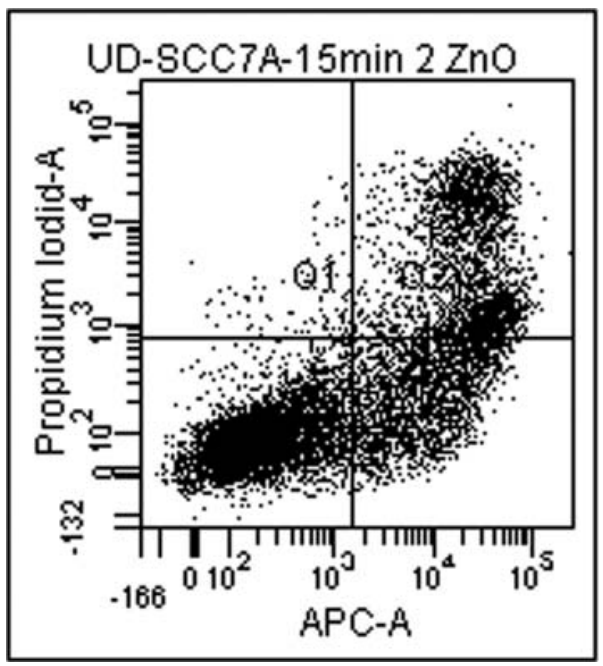

F

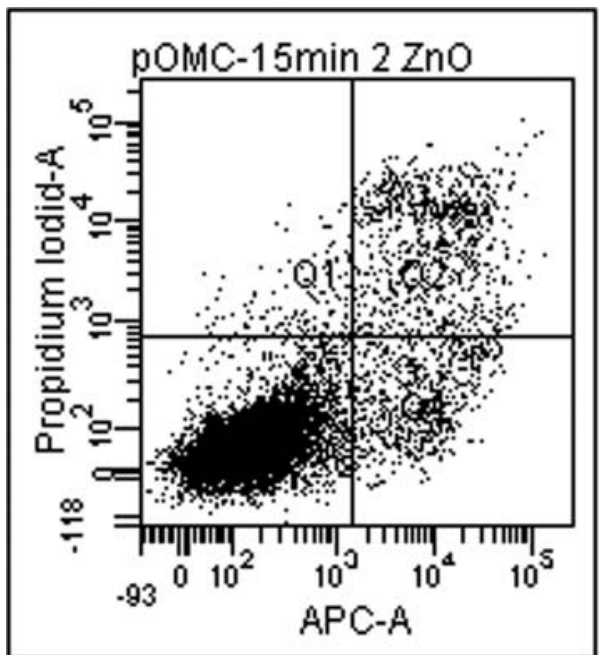

Figure 4. Dot plots of annexin V propidium iodide flow cytometry shows results for a $\mathrm{ZnO} \mathrm{NP}$ concentration of $2 \mu \mathrm{g} / \mathrm{ml}$ for $\mathrm{HLaC} 78$ without (A) and with UVA-1 treatment (B), for UD-SCC 7A without (C) and with UVA-1 (D) and for pOMCs without (E) and with UVA-1 treatment (F).

5 min of UVA-1 exposure, again there was no significant reduction in cell viability except for the concentration of $20 \mu \mathrm{g} / \mathrm{ml}$ both for tumour cells and pOMCs (Fig. 3B). However, a significant increase in cell viability was observed for $\mathrm{HLaC} 78$ after $10 \mathrm{~min}$ of irradiation and a $\mathrm{ZnO} \mathrm{NP}$ concentration of $2 \mu \mathrm{g} / \mathrm{ml}$ with $\mathrm{P}<0.05$ compared to the cells without NP exposure (Fig. 3C). Additionally, both tumour cell line samples treated with UVA-1 for 15 min presented a significant reduction in viable cells for $\mathrm{ZnO} \mathrm{NP}$ concentrations of $0.2(\mathrm{P}<0.05)$ and $2 \mu \mathrm{g} / \mathrm{ml}(\mathrm{P}<0.005)$ compared to 
the control group exposed to UVA-1 for 15 min without $\mathrm{ZnO}$ NPs (Fig. 3D). No cell killing effect could be observed in pOMCs for particle concentrations up to $2 \mu \mathrm{g} / \mathrm{ml}$. These results were confirmed in the FDA assay. Regarding concentrations below $20 \mu \mathrm{g} / \mathrm{ml}$, a significant reduction in tumour cell viability was observed for a UVA-1 irradiation for $15 \mathrm{~min}$ in combination with $\mathrm{ZnO} \mathrm{NP}$ exposure of 0.2 and $2 \mu \mathrm{g} / \mathrm{ml}$. No effect could be seen in pOMCs for concentrations below $20 \mu \mathrm{g} / \mathrm{ml}$.

Morphology changes of all cells were investigated by inverted phase-contrast microscopy. HNSCC cell lines treated with 0.2 and $2 \mu \mathrm{g} / \mathrm{ml}$ of ZnO NPs and UVA-1 for $15 \mathrm{~min}$ presented a condensed cellular shape as well as cellular swelling in some cases.

Flow cytometry. The annexin V-APC and PI assay was applied in order to quantitatively analyse apoptotic and necrotic cells under $\mathrm{ZnO} \mathrm{NP}$ treatment, including concentrations of 0 , $0.002,0.02,0.2$ and $2 \mu \mathrm{g} / \mathrm{ml}$, in combination with $15 \mathrm{~min}$ of UVA-1 treatment. Samples without NP and UVA-1 exposure served as negative control.

Regarding HLaC 78 cells without treatment, the rate of viable cells was $83.2 \%$. No increase in apoptosis or necrosis was seen for any of the tested concentrations of $\mathrm{ZnO}$ NPs. As a result of photocatalytic treatment, a significant increase in necrotic cells ranging from $11.7 \%$ in the sample without $\mathrm{ZnO}$ NPs up to $30.2 \%$ for a ZnO NP concentration of $2 \mu \mathrm{g} / \mathrm{ml}$ could be observed. In comparison, $20.4 \%$ of cells could be attributed to apoptosis in irradiated cells exposed to $2 \mu \mathrm{g} / \mathrm{ml}$ $\mathrm{ZnO}$ NPs. The percentage of apoptosis in the negative control was $8.0 \%$. Dot plots are presented for HLaC 78 treated with $2 \mu \mathrm{g} / \mathrm{ml} \mathrm{ZnO} \mathrm{NPs} \mathrm{with} \mathrm{(Fig.} \mathrm{4B)} \mathrm{and} \mathrm{without}$ UVA-1 (Fig. 4A).

For UD-SCC 7A, results were similar to HLaC 78. For samples without UVA-1 treatment, no increase in apoptosis or necrosis was measured. In contrast, a significant increase in necrotic tumour cells was seen for the concentrations 0.2 and $2 \mu \mathrm{g} / \mathrm{ml}$. Data are shown in Fig. 4C and D.

In pOMCs, no significant differences in apoptosis and necrosis rates between treated and untreated samples were observed. The percentage of apoptotic cells ranged between 5.8 and 7.2, and the percentage of necrotic cells between 7.2 and 8.6. Dot plots are shown for pOMCs treated with $2 \mu \mathrm{g} / \mathrm{ml}$ ZnO NPs with (Fig. 4F) and without UVA (Fig. 4E).

\section{Discussion}

Despite intense research on alternative treatment strategies for HNSCC, survival rates of these tumour entities could not be improved significantly over the last several decades (25). Due to the similar photocatalytic capacities of $\mathrm{TiO}_{2}$ NPs and $\mathrm{ZnO}$ NPs, both are utilized in the degradation of environmental pollutants. Photocatalytic-induced cell death of human tumour cell lines in vitro has been shown for $\mathrm{TiO}_{2} \mathrm{NPs}$ $(16,17,26)$ and synergistic cytotoxic effects with daunorubicin have been reported for two human leukaemia cell lines with respect to $\mathrm{ZnO}$ NPs (27). In contrast to NPs used for drug delivery in the context of photodynamic therapy, ZnO NPs are the supposed therapeutical active agents in case of photocatalytic reactions (28). The focus of the present study is the photocatalytic effect of ZnO NPs on HNSCC and pOMCs in vitro. The human HNSCC cell lines HLaC 78 and UD-SCC 7A as well as pOMCs were incubated with $\mathrm{ZnO} N \mathrm{NP}$ suspensions in concentrations ranging from 0.002 to $20 \mu \mathrm{g} / \mathrm{ml}$. Initially, sonication was performed to provide a low grade of particle aggregation.

As a first step, TEM was used to describe particle characteristics such as diameter, morphology and tendency of aggregation. $\mathrm{ZnO}$ NPs were rod shaped with a mean length of $79 \mathrm{~nm}$ and a mean lateral diameter of $46 \mathrm{~nm}$, thereby being well within the range of nanoparticle size. However, particle aggregates were seen despite dispersive sonication, indicating the strong tendency of nanoparticles to form aggregates in aqueous conditions. According to Bihari et al, pre-treatment procedures account for the grade of particle aggregation (19). High energy sonication and consecutive supplementation with proteins as stabilisers were shown to be the most effective procedures for dispersing NPs in suspension. In examining the intracellular distribution of NPs, equal percentages of the three different cell types were measured in terms of intracytoplasmic particle deposition, whereas a significant difference for particle transfer to the cell nucleus was observed. In HNSCC, $3.5 \%$ of cells contained $\mathrm{NP}$ aggregates in the nucleus compared to $0.5 \%$ in pOMCs. According to a recent report on the toxicological properties of $\mathrm{TiO}_{2}$ NPs, measurable DNA damage can be shown even if a minor fraction of the cells is exposed to a genotoxic substance (29). However, the mechanisms of nuclear particle uptake remain to be elucidated. These results raise the question as to why HNSCC cells show more intranuclear NPs than non-malignant pOMCs. A diameter of $40 \mathrm{~nm}$ is stated as the critical size for particle transfer to the nucleus (30). With respect to the data of the current study, particles, and especially particle aggregates, were larger than $40 \mathrm{~nm}$, indicating alternative transfer mechanisms. Since intranuclear $\mathrm{ZnO} \mathrm{NP}$ aggregates did not show a surrounding membrane, adherence to the chromatin during cell mitosis may be a possible explanation for uptake. A higher proliferation rate for $\mathrm{HLaC} 78$ and UD-SCC 7A compared to pOMCs has been measured. Therefore, mitosis-dependent mechanisms of nuclear particle uptake should be discussed as a possible parameter leading to significant differences between HNSCC and pOMCs. Moreover, the impact of NP distribution in cellular compartments on photocatalytic cell death indicates the need for further investigations on cellular and nuclear transfer mechanisms.

Results of the MTT test demonstrated a significant reduction in cell viability in both HNSCC cell lines by photoexcited $\mathrm{ZnO}$ NPs at concentrations of 0.2 and $2 \mu \mathrm{g} / \mathrm{ml}$ in combination with UVA-1 treatment for $15 \mathrm{~min}$. For HLaC 78 , a significant decrease in viable cells was already seen at an NP concentration of $2 \mu \mathrm{g} / \mathrm{ml}$ after $15 \mathrm{~min}$ of UVA-1 irradiation. No photocatalytic cell killing effect was shown in pOMCs. For concentrations up to $2 \mu \mathrm{g} / \mathrm{ml}$, a single exposure to $\mathrm{ZnO}$ NPs without UVA-1 irradiation did not influence cell viability for both tumour cell lines and mucosa cells. Additionally, no tumour cell death was induced by UVA-1 treatment alone, and UVA-1 irradiation below $10 \mathrm{~min}$ also did not decrease cancer cell viability. A significant reduction in cell viability could be observed for HNSCC and pOMCs 
exposed to $20 \mu \mathrm{g} / \mathrm{ml} \mathrm{ZnO} \mathrm{NPs} \mathrm{even} \mathrm{without} \mathrm{UVA-1} \mathrm{treatment.}$ This finding may be discussed as a cytotoxic property of Zno NPs which appears to be independent from its photocatalytic mechanisms.

Regarding HNSCC cells, a combination of late apoptosis and necrosis was observed in flow cytometry. Due to a predominance of necrosis, apoptotic cell death seems to play a minor role in $\mathrm{ZnO} \mathrm{NP}$-induced photocatalysis. Inverted phase-contrast microscopy showed contracted cells as well as cellular swelling. Initial damage of cell membranes by photoexcited ZnO NPs could be postulated as a theory for primary cell damage mechanisms, based on previous findings on photoreactions of $\mathrm{TiO}_{2}$ in malignant cells (16). Increased membrane permeability of tumour cells may lead to an extended intracellular uptake of nanoparticles and thus promote cell destruction.

The results of the current investigation correspond to photocatalytic properties of $\mathrm{ZnO}$ NPs. This appears especially remarkable since particles induced cytotoxic cell death exclusively in human squamous cell carcinoma cells, while leaving oral mucosa cells unaffected in vitro. Particle concentrations of 0.2 and $2 \mu \mathrm{g} / \mathrm{ml}$ in combination with a UVA-1 irradiation time of $15 \mathrm{~min}$ with a light intensity of $20 \mathrm{mWcm}^{-2}$ presented the optimal conditions for cancer cell treatment. Our initial experiences with photomedical approaches using low-dose $\mathrm{ZnO}$ NPs were promising. Compared to conventional oncological therapies like surgery, radiation or chemotherapy, photomedical treatment may prove to be a repeatable and minimally invasive novel method for use in conjunction with established regimes, and one that should be investigated more intensively in the future. Recent reports described combinations of fullerenes with pophyrin or gold nanoparticles conjugated with 5-aminolevulinic acid in order to create novel, nano-scaled agents for photodynamic therapy with improved properties concerning cell penetration and cancer cell killing $(31,32)$. Similar to the closely related photodynamic therapy, indication for nanoparticle-induced photocatalytic cancer treatment could be premalignant mucosa changes or palliative extended tumour formations. Further research should also focus on a more in-depth study of the mechanisms of cell death and the classification of the impact of photocatalytic reactions on the treatment of premalignant and malignant lesions in the head and neck.

\section{Acknowledgements}

The authors thank Jürgen Becker from the Department of Dermatology at the University of Wuerzburg, where the UVA-1 treatment was done, for providing the facilities. This study was supported in part by the Rudolf-Bartling-Stiftung.

\section{References}

1. Jemal A, Siegel R, Ward E, Hao Y, Xu JC and Thun MJ: Cancer statistics 2009. CA Cancer J Clin 59: 225-249, 2009.

2. Parthan A, Posner MR, Brammer C, Beltran P and Jansen JP: Cost utility of docetaxel as induction chemotherapy followed by chemoradiation in locally advanced squamous cell carcinomas of the head and neck. Head Neck 31: 1255-1262, 2009.

3. Marron M, Boffetta P, Zhang ZF, et al: Cessation of alcohol drinking, tobacco smoking and the reversal of head and neck cancer risk. Int J Epidemiol 39: 182-196, 2010.
4. Rogers SJ, Harrington KJ, Rhys-Evans P, O-Charoenrat P and Eccles SA: Biological significance of c-erbB family oncogenes in head and neck cancer. Cancer Metastasis Rev 24: 47-69, 2005.

5. Dias JD, Guse K, Nokisalmi P, Eriksson M, Chen DT, Diaconu I, Tenhunen M, Liikanen I, Grénman R, Savontaus M, Pesonen S, Cerullo V and Hemminki A: Multimodal approach using oncolytic adenovirus, cetuximab, chemotherapy and radiotherapy in HNSCC low passage tumour cell cultures. Eur J Cancer 46: 625-635, 2010.

6. Browman GP and Cronin L: Standard chemotherapy in squamous cell head and neck cancer: what we have learned from randomized trials. Semin Oncol 21: 311-319, 1994.

7. Reuter CW, Morgan MA and Eckardt A: Targeting EGFreceptor-signalling in squamous cell carcinomas of the head and neck. Br J Cancer 96: 408-416, 2007.

8. Emerich DF and Thanos CG: Nanotechnology and medicine. Expert Opin Biol Ther 3: 655-663, 2003.

9. Oberdörster G, Oberdörster E and Oberdörster J: Nanotoxicology: an emerging discipline evolving from studies of ultrafine particles. Environ Health Perspect 113: 823-839, 2005.

10. L'Azou B, Jorly J, On D, Sellier E, Moisan F, Fleury-Feith J, Cambar J, Brochard P and Ohayon-Courtès C: In vitro effects of nanoparticles on renal cells. Part Fibre Toxicol 19: 22, 2008.

11. Colvin V: The potential environmental impacts on engineered nanomaterials. Nature Biotechnol 21: 1166-1170, 2003.

12. Oberdörster E: Manufactured nanomaterials (Fullerenes, C60) induce oxidative stress in the brain of juvenile largemouth bass. Environ. Health Perspect 112: 1058-1062, 2004.

13. Veranth JM, Kaser EG, Veranth MM, Koch M and Yost GS: Cytokine responses of human lung cells (BEAS-2B) treated with micron-sized and nanoparticles of metal oxides compared to soil dusts. Part Fibre Toxicol 27: 2, 2007.

14. Yeber MC, Rodriguez J, Freer J, Duran N and Mansilla HD: Photocatalytic degradation of cellulose bleaching effluent by supported $\mathrm{TiO}_{2}$ and $\mathrm{ZnO}$. Chemosphere 41: 1193-1197, 2000.

15. Theogaraj E, Riley S, Hughes L, Maier M and Kirkland D: An investigation of the photo-clastogenic potential of ultrafine titanium dioxide particles. Mutat Res 634: 205-219, 2007.

16. Zhang AP and Sun YP: Photocatalytic killing effect of $\mathrm{TiO}_{2}$ nanoparticles on Ls-174-t human colon carcinoma cells. World J Gastroenterol 10: 3191-3193, 2004.

17. Seo JW, Chung H, Kim MY, Lee J, Choi IH and Cheon J: Development of water-soluble single-crystalline $\mathrm{TiO}_{2}$ nanoparticles for photocatalytic cancer-cell treatment. Small 3: 850-853, 2007.

18. Li D and Haneda H: Morphologies of zinc oxide particles and their effects on photocatalysis. Chemosphere 51: 129-137, 2003.

19. Bihari P, Vippola M, Schultes S, Praetner M, Khandoga AG, Reichel CA, Coester C, Tuomi T, Rehberg M and Krombach F: Optimized dispersion of nanoparticles for biological in vitro and in vivo studies. Part Fibre Toxicol 6: 14, 2008.

20. Zenner HP, Lehner W and Herrmann IF: Establishment of carcinoma cell lines from larynx and submandibular gland. Arch Otorhinolaryngol 225: 269-277, 1979.

21. Balló H, Koldovky P, Hoffmann T, Balz V, Hildebrandt B, Gerharz CD and Bier H: Establishment and characterization of four cell lines derived from human head and neck squamous cell carcinomas for an autologous tumor-fibroblast in vitro model. Anticancer Res 19: 3827-3836, 1999.

22. Schmidt M, Polednik C, Gruensfelder P, Roller J and Hagen R: The effects of PC-Spes on chemosensitive and chemoresistant head and neck cancer cells and primary mucosal keratinocytes. Oncol Rep 21: 1297-1305, 2009.

23. Mosmann T: Rapid colorimetric assay for cellular growth and survival: application to proliferation and cytotoxicity assays. J Immunol Methods 65: 55-63, 1983.

24. Majno G and Joris I: Apoptosis, oncosis, and necrosis: an overview of cell death. Am J Pathol 146: 3-15, 1995.

25. Wagenblast J, Baghi M, Arnoldner C, Bisdas S, Gstöttner W, May A, Knecht R and Hambek M: Effects of combination treatment of bortezomib and dexamethasone in SCCHN cell lines depend on tumor cell specificity. Oncol Rep 20: 1207-1211, 2008.

26. Fujishima A, Cai RX, Otsuki J, Hashimoto K, Itoh K, Yamashita $\mathrm{T}$ and Kobuta Y: Biochemical application of photoelectrochemistry: photokilling of malignant cells with $\mathrm{TiO}_{2}$ powder. Electrochimica Acta 38: 153-157, 1993. 
27. Guo D, Wu C, Jiang H, Li Q, Wang X and Chen B: Synergistic cytotoxic effect of different sized $\mathrm{ZnO}$ nanoparticles and daunorubicin against leukaemia cancer cells under UV irradiation. J Photochem Photobiol B 93: 119-126, 2008.

28. Camerin M, Magaraggia M, Soncin M, Jori G, Moreno M, Chambrier I, Cook MJ and Russell DA: The in vivo efficacy of phthalocyanine-nanoparticle conjugates for the photodynamic therapy of amelanotic melanoma. Eur J Cancer (In press).

29. Hackenberg S, Friehs G, Froelich K, Ginzkey C, Koehler C, Scherzed A, Burghartz M, Hagen R and Kleinsasser N: Intracellular distribution, geno- and cytotoxic effects of nanosized titanium dioxide particles in the anatase crystal phase on human nasal mucosa cells. Toxicol Lett 195: 9-14, 2010.
30. Geiser M, Rothen-Rutishauser B, Kapp N, Schuerch S Kreyling W, Schulz H, Semmler M, Im Hof V, Heyder J and Gehr P: Ultrafine particles cross cellular membranes by nonphagocytic mechanism in lungs and in cultured cells. Environ Health Perspect 113: 1555-1560, 2005.

31. Constantin C, Neagu M, Ion RM, Gherghiceanu M and Stavaru C: Fullerene-porphyrin nanostructures in photodynamic therapy. Nanomedicine 5: 307-317, 2010.

32. Oo MKK, Yang X, Du H and Wang H: 5-aminolevulinic acidconjugated gold nanoparticles for photodynamic therapy of cancer. Nanomedicine 3: 777-786, 2008. 